\title{
PERBANDINGAN pH DAN DAYA SEBAR KRIM EKSTRAK KULIT NANAS (Ananas comosus (L). Merr)
}

\author{
Indra Gunawan \\ Jurusan Farmasi Politeknik Kesehatan Tanjungkarang
}

\begin{abstract}
Abstrak
Penyakit kulit akibat jamur merupakan insiden nomor tiga dari seluruh kasus penyakit kulit di Indonesia setelah penyakit infeksi dan alergi. Penelitian ekstrak kulit nanas (Ananas comosus (L) Merr.) terbukti mempunyai daya hambat tehadap pertumbuhan jamur Trichophyton rubrum dengan rata-rata diameter zona hambat 24,6 mm. Penelitian bertujuan untuk mendapatkan krim ekstrak kulit nanas (Ananas comosus (L) Merr.) dengan konsentrasi nanas biasa 10\% (F1), 12\% (F2), nanas madu 10\% (F3), 12\% (F4) serta kontrol negatif (F0) yang memenuhi persyaratan sediaan krim. Pembuatan krim esktrak kulit nanas menggunakan fase minyak dalam air. Bahan yang digunakan dalam formulasi; asam stearat, cera alba, vaselin album, triethanolamine, propilen glikol, dan aquades. Uji daya sebar dilakukan untuk melihat diameter penyebaran krim dan uji $\mathrm{pH}$ krim dilakukan menggunakan pembanding $\mathrm{pH}$ kulit manusia. Hasil penelitian menunjukkan bahwa krim ekstrak kulit nanas biasa dan nanas madu (Ananas comosus (L) Merr.) berwarna coklat muda, berbau khas, dan memiliki tekstur setengah padat cenderung padat. $\mathrm{pH}$ krim yang memenuhi persyaratan adalah F2, F3, dan F4. Hasil pengolahan Several Independent Test menggunakan uji Kruskal-Wallis H terhadap $\mathrm{pH}$ dan daya sebar (F0, F1, F2, F3, dan F4) didapatkan hasil nilai $\operatorname{Sig}<\alpha$ (nilai $\alpha=0,05$ ) yang berarti nilai nya berbeda secara signifikan.
\end{abstract}

Kata Kunci : pH, Daya Sebar, Krim, Ekstrak Kulit Nanas

\section{COMPARISON OF pH AND POWER SPREAD PINEAPPLE SKIN EXTRACT CREAM (Ananas comosus (L). Merr)}

\begin{abstract}
Skin disease caused by fungi is incident number three of all cases of skin disease in Indonesia after infectious disease and allergies. Research skin extract pineaplle shown to have inhibition of fungal growth Trichophyton rubrum with the average diameter of the inhibition zone $24,6 \mathrm{~mm}$. The research aims to obtain the pineapple skin extract cream (Ananas comosus (L) Merr.) with the concentration of the usual pineapple 10\% (F1), 12\% (F2), honey pineapple $10 \%(\mathrm{~F} 3), 12 \%(\mathrm{~F} 4)$ as well as negative control (F0) which meet the requirement of the cream dosage form. The manufacture the pineapple skin extract cream using the oil phase in water. The material used in formulation; stearic, cera alba, white vaseline, triethanolamine, propylene glycol, and distilled water. Spreadibility test is done to see the cream spread diameter and The test of $\mathrm{pH}$ was done by comparing with The $\mathrm{pH}$ of skin. The result showed that the usual pineapple skin extract and honey pineapple (Ananas comosus (L) Merr.) colored light brown, characteristic odor, and has the texture of semi-solid likely solid extract pineapple. The $\mathrm{pH}$ of the cream that meets the requirement is F2, F3, dan F4. The results of processing Several Independent Test using the Kruskal-Wallis $\mathrm{H}$ against $\mathrm{pH}$ and spread power (F0, F1, F2, F3, dan F4) results obtained value of $\operatorname{Sig}<\alpha$ (value $\alpha=0,05$ ) that mean value is significantly different.
\end{abstract}

Keyword : pH, Power of Spread, Cream, Pineapple Skin Extract

Korespondensi : Indra Gunawan, Jurusan Farmasi Politeknik Kesehatan Tanjungkarang, Jl Soekarno Hatta No.1 Bandar Lampung, Mobile +628117962017, e-mail : kangigun2017@gmail.com 


\section{Pendahuluan}

Indonesia merupakan negara tropis dengan kelembaban udara yang tinggi. Kondisi tersebut membuat penduduknya menjadi rentan dihinggapi berbagai macam penyakit, salah satunya adalah penyakit kulit yang disebabkan oleh jamur. Saat ini terdapat lebih dari 200.000 spesies jamur yang terdapat di alam bebas dan 100 spesies diantaranya dapat bersifat patogen terhadap manusia. Jamur dapat menimbulkan kelainan pada manusia apabila berada pada keadaan yang menguntungkan untuk pertumbuhannya (Gandahusada dkk, 2006). Penyakit kulit akibat jamur merupakan insiden nomor tiga dari seluruh kasus penyakit kulit di Indonesia setelah penyakit infeksi oleh bakteri dan penyakit kulit karena alergi (Siregar, 2005).

Penyakit kulit yang banyak terdapat di daerah tropis khususnya Indonesia adalah kurap, panu, kudis, dan eksim. Kurap atau Tinea corporis adalah infeksi jamur dermatofita pada kulit halus di daerah muka, badan, lengan, dan glutea. Penyebab tersering penyakit ini adalah Trichophyton rubrum. Pengobatan Tinea corporis dapat diterapi secara topikal maupun sistemik. Obat-obat yang sering dipakai antara lain ketokonazol, mikonazol, bifonazol, dan klotrimazol (Gandahusada, 2006).

Obat tradisional adalah bahan atau ramuan bahan yang berupa bahan tumbuhan, bahan hewan, bahan mineral, sediaan sarian (galenik), atau campuran dari bahan tersebut yang secara turun temurun telah digunakan untuk pengobatan, dan dapat diterapkan sesuai dengan norma yang berlaku di masyarakat (Depkes RI, 2009).

Hasil penelitian yang dilakukan oleh Damogalad, dkk (2013), ekstrak kulit nanas (Ananas comosus (L) Merr.) yang dibuat dalam formulasi krim tabir surya dan uji in vitro nilai sun protecting factor (SPF) dengan konsentrasi $2 \%, 4 \%$ dan $8 \%$ menunjukkan konsentrasi $2 \%$ dan $4 \%$ tidak masuk dalam pembagian tingkat kemampuan tabir surya, sedangkan konsentrasi 8\% memiliki tingkat kemampuan minimal SPF.

Tanaman Nanas (Ananas comosus (L) Merr.) pertama kali ditemukan oleh Colombus pada saat mendarat di Amerika Selatan. Buah nanas merupakan buah yang spesial, karena selain harganya terjangkau, nanas juga mempunyai banyak manfaat yang berkhasiat untuk kesehatan. Pada dasarnya, pohon nanas bisa tumbuh dimana saja (Siswoyo, 2009). Kulit nanas mengandung 81,72\% air, 20,87\% serat kasar, $17,53 \%$ karbohidrat, 4,41\% protein, enzim bromelain, $13,65 \%$ gula reduksi, flavonoid, dan tanin (Nuraini, 2011).

Tumbuhan yang mengandung flavonoid banyak dipakai dalam pengobatan tradisional. Hal tersebut disebabkan flavonoid mempunyai berbagai macam aktivitas terhadap macammacam organisme (Robinson, 1995). Penelitian farmakologi terhadap senyawa flavonoid menunjukkan bahwa beberapa golongan flavonoid memperlihatkan aktivitas seperti antifungi, diuretik, antivirus dan menghambat kerja enzim (Geissman, 1962).

Tujuan penelitian ini untuk mendapatkan produk sediaan krim ekstrak kulit nanas biasa dan nanas madu (Ananas comosus (L) Merr.) dengan konsentrasi masing-masing $10 \%$ dan $12 \%$, serta kontrol negatif kemudian dilakukan pengujian terhadap sifat fisik (organoleptik), $\mathrm{pH}$, dan daya sebar.

\section{Metode}

Jenis penelitian bersifat terapan (aplikatif) yang dilakukan dengan tujuan menerapkan, menguji dan mengevaluasi kemampuan suatu teori yang diterapkan dalam memecahkan masalah-masalah praktis (Sugiyono, 2009). Desain penelitian yang digunakan adalah riset eksperimental, yang bertujuan untuk mengetahui suatu gejala atau pengaruh yang timbul, sebagai akibat dari adanya perlakuan tertentu (Notoatmodjo, 2010)

Penelitian telah dilakukan pada bulan Agustus tahun 2017 di Laboratorium Farmasetika Jurusan Farmasi Politeknik Kesehatan Tanjungkarang dan Laboratorium Kimia Fakultas Matematika dan Ilmu Pengetahuan Alam (MIPA) Universitas Lampung.

Sampel yang digunakan dalam penelitian adalah seluruh populasi yang digunakan dalam penelitian yaitu formulasi krim yang mengandung ekstrak kulit nanas biasa dan nanas madu (Ananas comosus (L) Merr.) dengan masing-masing konsentrasi 10\%, 12\% dan kontrol negatif dengan pengulangan sebanyak 5 (lima) kali pengulangan sehingga seluruhnya berjumlah 15 sediaan krim.

Penelitian ini dilakukan dengan membuat formulasi krim yang mengandung ekstrak kulit nanas biasa dan nanas madu (Ananas comosus (L) Merr.) dengan masing-masing konsentrasi $10 \%$, $12 \%$ dan kontrol negatif, serta mengevaluasi sifat fisik berupa organoleptis, $\mathrm{pH}$, daya sebar, dan aseptabilitas sediaan. 
Cara kerja pembuatan ekstrak kulit nanas, krim, uji $\mathrm{pH}$ dan uji daya sebar dilakukan sebagai berikut:

1. Ekstrak Kulit Nanas

Kulit nanas biasa diperoleh dari pasar pagi bambu kuning Bandar Lampung sedangkan kulit nanas madu diperoleh dari pedagang nanas madu di Jalan Zainal Abidin Pagar Alam Bandar Lampung. Kulit nanas diolah dengan cara mengupas kulit dari buahnya dan diusahakan agar buah nanas tidak ikut terkupas bersama kulitnya, dicuci hingga bersih kemudian merajangnya menjadi kecil-kecil. Kulit nanas yang digunakan sebanyak 500 gram direndam dalam alkohol 70\% szebanyak 3 liter selama 24 jam. Perendaman dilakukan tiga kali dengan jumlah pelarut yang sama. Selanjutnya dilakukan penguapan dengan menggunakan evaporator hingga mendapat ekstrak kental. Bobot yang diperoleh adalah 60,23 gram. Ekstrak berwarna coklat kehitaman dan berbau khas nanas.

2. Krim Ekstrak Kulit Nanas

Pembuatan krim dilakukan dengan cara melebur fase minyak dan fase air pada cawan porselen. Fase air dituangkan ke fase minyak yang sudah terdapat dilumpang, ketika suhu sama-sama panas digerus cepat hingga terbentuk basis krim yang bagus (homogen dan tidak pecah), selanjutnya ekstrak kulit nanas biasa dan nanas madu (Ananas comosus (L) Merr.) dicampurkan kedalam basis. Apabila zat aktif berupa ekstrak kental maka digerus dahulu dengan sedikit air (Anief, 2010) setelah itu krim gerus hingga homogen. Pada umumnya krim dibuat dengan melelehkan bahan-bahan krim berupa lemak pada suhu $70^{\circ} \mathrm{C}$. Memanaskan bahan-bahan krim larut air pada suhu $70^{\circ} \mathrm{C}$, kemudian perlahan-lahan menuangkannya kedalam lelehan lemak, diaduk homogen hingga dingin (Depkes RI, 2009).

3. Pengujian $\mathrm{pH}$ krim

Pengujian $\mathrm{pH}$ dilakukan dengan menggunakan buffer $\mathrm{pH} 7$, dengan cara mencelupkan $\mathrm{pH}$ meter terhadap sediaan krim yang telah dilarutkan terlebih dahulu dengan perbandingan $60 \mathrm{~g}: 200 \mathrm{ml}$ air.

4. Pengujian Daya Sebar

Penilaian uji daya sebar dilakukan dengan cara sebanyak 1 gram sediaan krim diletakkan di atas kaca berukuran $20 \times 20 \mathrm{~cm}$ yang telah diberi spot area. Selanjutnya ditutup dengan kertas mika dan diberikan pemberat diatasnya dengan bobot mencapai 125 gram, kemudian diukur diameter yang terbentuk setelah 1 menit.

\section{Hasil}

Hasil pengujian organoleptik krim ekstrak kulit nanas biasa dan nanas madu (Ananas comosus (L) Merr.) berdasarkan warna, bau, dan tekstur didapatkan hasil yaitu; berwarna coklat muda, berbau khas, dan memiliki tekstur setengah padat cenderung padat.

Tabel 1. Hasil pengujian organoleptik krim ekstrak kulit nanas

\begin{tabular}{cccc}
\hline Formula & \multicolumn{3}{c}{ Organoleptik } \\
\cline { 2 - 4 } Krim & Warna & Bau & Tekstur \\
\hline F0 & Putih & Tidak berbau & Setengah padat cenderung cair \\
F1 & Coklat muda & Berbau khas & Setengah padat cenderung padat \\
F2 & Coklat muda & Berbau khas & Setengah padat cenderung padat \\
F3 & Coklat muda & Berbau khas & Setengah padat cenderung padat \\
F4 & Coklat muda & Berbau khas & Setengah padat cenderung padat \\
\hline
\end{tabular}

Hasil pengujian pH krim ekstrak kulit nanas dapat dilihat pada tabel 2 dibawah ini.

Tabel 2. Hasil pengujian pH krim ekstrak kulit nanas

\begin{tabular}{cccccccc}
\hline $\begin{array}{c}\text { Formula } \\
\text { Krim }\end{array}$ & \multicolumn{9}{c}{$\begin{array}{c}\text { pH } \\
\text { (5 kali pengulangan) }\end{array}$} & $\begin{array}{c}\text { Rata- } \\
\text { rata }\end{array}$ & Keterangan \\
\hline F0 & 7,1 & 7,3 & 6,9 & 7,2 & 7,0 & 7,1 & TMS \\
F1 & 6,9 & 7,1 & 6,7 & 6,9 & 6,8 & 6,8 & TMS \\
F2 & 6,7 & 6,5 & 6,2 & 6,7 & 6,7 & 6,5 & MS \\
F3 & 6,3 & 6,2 & 6,5 & 6,0 & 6,1 & 6,2 & MS \\
F4 & 6,1 & 6,1 & 5,9 & 6,2 & 5,7 & 6,0 & MS \\
\hline
\end{tabular}


Keterangan :

MS : Memenuhi syarat nilai $\mathrm{pH}$ fisiologis kulit manusia

TMS : Tidak memenuhi syarat nilai $\mathrm{pH}$ fisiologis kulit manusia

Berdasarkan Tabel 2. krim F2, F3, dan F4 memenuhi syarat nilai $\mathrm{pH}$ fisiologis kulit manusia, sedangkan $\mathrm{F} 0$ dan $\mathrm{F} 1$ tidak memenuhi syarat nilai $\mathrm{pH}$ fisiologis kulit manusia (pH kulit manusia yaitu 4,5-6,5). Hasil pengolahan statistik Several Independent Test menggunakan uji Kruskal-Wallis $\mathrm{H}$ terhadap nilai $\mathrm{pH}$ semua formula $\mathrm{krim}(\mathrm{F} 0, \mathrm{~F} 1, \mathrm{~F} 2$, F3, dan F4) didapatkan hasil nilai Sig adalah 0. Pengujian hipotesis yaitu Ho ditolak, karena Sig. $<\alpha$ (nilai $\alpha=0,05)$.

Hasil pengujian daya sebar ekstrak kulit nanas dapat dilihat pada tabel 3 dibawah ini.

Tabel 3. Hasil uji daya sebar ekstrak krim kulit nanas.

\begin{tabular}{cccccccc}
\hline $\begin{array}{c}\text { Formula } \\
\text { Krim }\end{array}$ & \multicolumn{4}{c}{$\begin{array}{c}\text { Daya Sebar } \\
\text { (5 }\end{array}$ kali pengulangan) } & $\begin{array}{c}\text { Rata- } \\
\text { rata }\end{array}$ \\
\hline F0 & 6,0 & 6,2 & 6,3 & 6,2 & 5,9 & 6,1 \\
F1 & 5,2 & 5,0 & 5,1 & 5,3 & 5,2 & 5,1 \\
F2 & 4,6 & 4,5 & 4,0 & 4,2 & 4,1 & 4,2 \\
F3 & 4,1 & 4,7 & 4,2 & 4,4 & 4,3 & 4,3 \\
F4 & 4,0 & 4,2 & 4,1 & 4,5 & 3,9 & 4,1 \\
\hline
\end{tabular}

Berdasarkan hasil pengolahan statistik Several Independent Test menggunakan uji Kruskal-Wallis $\mathrm{H}$ terhadap nilai daya sebar semua formula krim (F0, F1, F2, F3, dan F4) didapatkan hasil nilai Sig adalah 0.001, Pengujian hipotesis yaitu Ho ditolak, karena Sig. $<\alpha$ (nilai $\alpha=0,05)$.

\section{Pembahasan}

Hasil rendemen ekstrak kulit nanas yang diperoleh berwarna coklat kehitaman. Hasil rendemen ekstraksi kulit nanas dengan sampel kulit nanas basah dan kering diperoleh hasil warna ekstrak berwarna coklat tua atau kehitaman yang mengindikasikan terdapat senyawa flavonoid yang ikut terekstrak (Setiawan, 2015). Kulit nanas mengandung senyawa flavonoid, alkaloidsteroid, tanin, dan saponin (Kalaisevi dkk, 2012).

Krim ekstrak kulit nanas yang dihasilkan memiliki tekstur setengah padat cenderung padat (Tabel 1.). Berdasarkan hasil tersebut maka krim yang dihasilkan masih belum memenuhi syarat sediaan krim yang baik, karena cenderung memiliki bentuk pasta dibandingkan krim. Hal ini dikarenakan proporsi air yang digunakan pada basis krim (F0) digantikan dengan ekstrak kental (F1, F2, F3, F4). Krim adalah sediaan setengah padat berupa emulsi mengandung air tidak kurang dari $60 \%$ dan dimaksudkan untuk pemakaian luar (Depkes RI, 1979).

Pada pengujian $\mathrm{pH}$ yang telah dilakukan, $\mathrm{pH}$ krim F0 tidak memenuhi syarat $\mathrm{pH}$ kulit yaitu 4,5-6,5 (Tranggono dan Latifah, 2007). Namun terjadi penurunan $\mathrm{pH}$ ketika ekstrak ditambahkan kedalam formula krim F1 dengan konsentrasi ekstrak 10\% memiliki pH 6,8, dikarenakan $\mathrm{pH}$ ekstrak kulit nanas yang dihasilkan asam yaitu 6,3, sehingga terjadi penurunan $\mathrm{pH}$. Namun $\mathrm{F} 1$ masih belum memenuhi syarat $\mathrm{pH}$ kulit. $\mathrm{pH}$ sediaan yang belum memenuhi nilai $\mathrm{pH}$ disebabkan karena didalam formula krim terdapat triethanolamin yang memiliki $\mathrm{pH}$ bersifat basa sehingga krim yang dihasilkan cenderung bersifat netral. Kegunaan triethanolamin sebagai zat pembasa (alkalizing) dan zat pengemulsi (Widodo, 2013).

Fomulasi krim F2, F3, dan F4 memenuhi syarat pH kulit, yaitu berkisar antara 6,0-6,5. Peningkatan konsentrasi ekstrak yang ditambahkan dan perbedaan jenis nanas mengakibatkan terjadinya penurunan $\mathrm{pH}$ pada sediaan krim. Perlu dilakukan penggunaan formula lain untuk zat pengemulsi yang tidak mengandung triethanolamin sebagai zat pembasa (alkalizing). Perbedaan formula krim secara signifikan mempengaruhi nilai $\mathrm{pH}$ yang dihasilkan, sehingga diperlukan preformulasi yang lebih baik agar didapat nilai $\mathrm{pH}$ yang memenuhi persyaratan $\mathrm{pH}$ kulit.

Hasil pengujian daya sebar dilakukan untuk mengetahui diameter penyebaran krim yang telah dibuat dengan meletakkan krim sebanyak 1 gram diatas kaca berukuran 20x20 $\mathrm{cm}$ yang telah diberi spot area lalu ditutup dengan kertas mika dan diberi pemberat berupa anak timbangan 125 gram ditunggu hingga 1 menit.. Setelah dilakukan pengujian didapat diameter penyebaran krim untuk formula F0 ialah 6,1. Sedangkan diameter penyebaran krim untuk formula F1 semakin kecil yaitu 5,1. Formulasi F2, F3, dan F4 hasil yang didapat berkisar antara 4,1-4,3. Sampai saat ini memang belum ada literatur berapakah diameter krim yang memenuhi syarat sediaan. Namun pengujian daya sebar harus tetap dilakukan 
untuk mengetahui penyebaran krim dan melihat apakah terdapat perbedaan daya sebar sebelum dan sesudah adanya perlakuan.

Keuntungan krim ialah mudah menyebar rata (Widodo, 2013). Hal tersebut dikarenakan ekstrak yang digunakan ialah ekstrak kental, semakin tingginya penambahan ekstrak kedalam sediaan krim maka, semakin rendah nilai daya sebar yang dihasilkan sehingga krim cenderung menjadi lebih padat dan mempengaruhi krim pada saat pengujian daya sebar yang membuat sediaan tersebut menjadi cenderung lebih padat. Perbedaan formulasi sediaan krim secara signifikan mempengaruhi nilai daya sebar yang dihasilkan.

Kesimpulan hasil penelitian ini yaitu hasil pengujian $\mathrm{pH}$ terhadap masing-masing krim; F0 dan F1 tidak memenuhi syarat, F2, F3, dan F4 memenuhi syarat. Hasil pengujian daya sebar terhadap masing-masing krim : $\mathrm{F} 0=6,1$ $\mathrm{F} 2=5,1 \mathrm{~F} 3=4,2 \mathrm{~F} 4=4,3 \mathrm{~F} 5=4,1$. Nilai $\mathrm{pH}$ dan daya sebar formulasi masing-masing krim berbeda secara signifikan.

Saran yang dapat disampaikan yaitu perlu dilakukan penggunaan formula krim yang berbeda karena kontrol sediaan krim pada penelitian ini menghasilkan nilai $\mathrm{pH}$ yang tidak memenuhi persyaratan $\mathrm{pH}$ kulit, dan perlu dilakukan penelitian uji antifungi terhadap sediaan krim untuk mengetahui efektivitas sediaan krim terhadap pengobatan kurap.

\section{Daftar Pustaka}

1. Anief, Moh., 2010. Ilmu Meracik Obat. Gajah Mada University Press: Yogyakarta

2. Damogalad, V., Edy H.J., Supriati, H.S., 2013. Formulasi Krim Tabir Surya Ekstrak Kulit Nanas (Ananas comosus (L) Merr.) dan Uji in Vitro Nilai Sun Protecting Factor (SPF), Jurnal Ilmiah Farmasi, Mei, Vol. 2, No. 2 hal 42.

3. Depkes RI, 1979, Farmakope Indonesia, Edisi III, Departemen Kesehatan Republik Indonesia, Jakarta.

4. Depkes RI, 2009. Undang-Undang Republik Indonesia Nomor 36 Tahun 2009 Tentang Kesehatan. Jakarta: Depkes RI.

5. Gandahusada, S., Lahude H.D., Pribadi W. 2006. Parasitologi Kedokteran Edisi III. Jakarta: Balai Penerbit FKUI.
6. Geissman, T.A,, 1962, The Chemistry of Flavonoid Counpound,.Oxford: Pergamon Press.

7. Kalaisevi, M., Gomanthi D., dan Uma, C., 2012, Occurence of Bioactive Compounds in Ananus comosus $L$ : A Standardization by HPTLC. Asian Pacific Journalof Tropical Biomedicine, page 1342-1346.

8. Notoatmodjo, S., 2010. Metodologi Penelitian Kesehatan. Jakarta: PT Rineka Cipta.

9. Nuraini, D.N., 2011. Aneka Manfaat Kulit Buah dan Sayuran. Yogyakarta: Andi Offset.

10. Setiawan, M.H., 2013. Isolasi dan Uji Daya Antimikroba Ekstrak Kulit Nanas (Ananas comosus (L) Merr.), Skripsi Fakultas MIPA Universitas Negeri Semarang, hal 31.

11. Siregar, 2005. Atlas Berwarna Saripati Penyakit Kulit. Jakarta: EGC.

12. Siswoyo, P., 2009. Tumbuhan Berkhasiat Obat. Yogyakarta: Absolut.

13. Sugiyono, 2009. Metode Penelitian Kuantitatif-Kualitatif dan $R \& D$, Bandung: Alfabeta

14. Tranggono, R. I., Latifah, F., 2007. Buku Pegangan Ilmu Pengetahuan Kosmetik. Jakarta: Gramedia Pustaka Utama.

15. Widodo, H., 2013. Ilmu Meracik Obat untuk Apoteker. Yogyakarta: D-Medika 